\title{
LITURGIA DAS EXÉQUIAS \\ EM TEMPOS DE PANDEMIA
}

\author{
Dr. Pe. Clair Favreto*
}

DOI: https://doi.org/10.52451/teopraxis.v37i129.10

Recebido: 06 de janeiro de 2019 | Aprovado: 04 de maio de 2019

Resumo: O presente artigo faz uma relação entre o significado da Liturgia, mais precisamente da Liturgia das exéquias, com seus ritos e, ao mesmo tempo, em relação a este tempo particular que a humanidade está vivendo, que é um tempo de pandemia. Serão resgatados os principais elementos do ritual das exéquias e de sua importância para acompanhar o irmão falecido, mas que foram dificultados pelo isolamento social provocados pela pandemia. $\mathrm{O}$ artigo também reflete algumas questões ligadas à morte iluminadas por alguns documentos da Igreja que trazem presente a teologia na vida eterna.

Palavras-chave: Liturgia. Exéquias. Páscoa. Morte. Igreja. Acompanhamento. Pandemia.

\section{Introdução}

No primeiro parágrafo da Instrução Geral do Ritual das Exéquias (IGRE), também chamada de Introdução Geral, Instrução Geral ou Preanotanda, encontramos a seguinte afirmação: "A Igreja celebra com profunda esperança o Mistério Pascal de Cristo nas exéquias de seus filhos, para que eles, incorporados pelo Batismo a Cristo morto e ressuscitado, passem com Ele da morte à vida" (IGRE 1).

Esta afirmação teológica presente na Preanotanda nos ajuda a entender e alimentar a nossa fé de que a vida é sempre voltada para o eterno. Celebrar as exéquias, portanto, é viver

* Padre da Diocese de Erexim. Professor da Itepa Faculdades nas disciplinas de Liturgia e Sacramentos. Reitor do Seminário São José - Passo Fundo. Doutor em Liturgia pelo Instituto de Liturgia Pastoral - Pádua/Itália. Email: clairfavreto@hotmail.com 
profundamente esta verdade afirmada pela Igreja: a morte nos faz mergulhar definitivamente no Mistério Pascal de Cristo. Esta ideia vai ser pano de fundo deste artigo que, ao mesmo tempo, quer relacionar ao contexto de epidemia pela qual estamos passando.

Num primeiro momento é importante resgatar a origem das palavras do enunciado. Em seguida, será feita uma relação "paralelo" - entre o significado do "acompanhamento" que nos propõe o atual Ritual das Exéquias e a situação de isolamento que a pandemia tem provocado. Por fim, trazendo presente algumas questões ligadas à morte, o artigo procura resgatar a teologia da Igreja presente na instrução e nas orações do atual Ritual das Exéquias.

\section{Recuperando o sentido etimológico do enunciado}

O título enunciado é Liturgia das Exéquias em tempos de pandemia. Antes de tudo, convém fazer um rápido resgate do sentido etimológico das palavras que compõem o enunciado para, posteriormente, fazer referência ao que elas implicam para o contexto da atual pandemia.

\section{a) Liturgia}

$O$ termo Liturgia tem sua origem na língua grega $\lambda$ eıtoupría (Leitourghía) e é formado por outros dois termos:

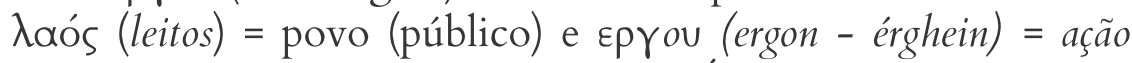
(obra) ou (erg-ia) - (sufixo) = trabalho. É desta combinação que surge o substantivo leitourghía, que significa ação ou serviço prestado em favor de um povo, um serviço prestado para o bem de um povo. Do substantivo leitourghía podemos chegar ao verbo leitourghein, que significa exercer função pública ou exercer um serviço público. 


\section{b) Exéquias}

Já o termo exéquias vem do latim = ex-sequi, ex-sequiae e significa seguir, acompanhar, estar presente... Exéquias, portanto, é uma série de ritos e orações pelas quais a comunidade cristã acompanha os seus defuntos e os encomenda à bondade de Deus.

Em todas as épocas da história e da cultura é possível perceber que todos os povos, através de ritos dos mais variados e expressivos, acompanhavam seus entes queridos até os locais de suas sepulturas. "Nas diversas culturas e religiões faz-se com orações e ritos, com os quais se quer exprimir o apreço pelo defunto, a recordação que dele se vai continuar a ter, a petição à divindade para que o tenha na sua paz ou, inclusive, a ajuda que

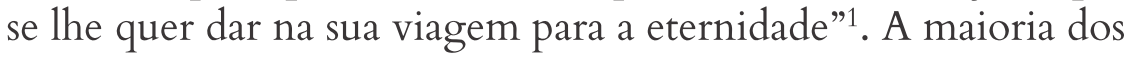
povos também realiza rituais de recordação e de veneração de seus antepassados mortos, principalmente em datas importantes.

Em algumas culturas ou países, o termo usado para as cerimônias de sepultura é chamado de funeral (do latim funus, funeris) que significa a cerimônia ou o ofício religioso realizado em torno dos defuntos ou para os defuntos. É dali que se originam os termos fúnebre (diz respeito ao óbito); funerária (empresa, equipe ou organização que realiza os atos fúnebres); aviso fúnebre (anúncio da morte de alguém).

Outro termo usado e que se aproxima dos rituais de exéquias é sufrágio. Este termo, vem do latim suffragium, suffragari e daí a raiz verbal frangere que significa partir, romper. Neste sentido, o termo sufrágio quer significar os atos litúrgicos que se realizam em favor dos defuntos.

Os cristãos, desde o início, também faziam seus rituais fúnebres pelos seus irmãos e irmãs falecidos. $\mathrm{O}$ primeiro relato, o encontramos no sepultamento de Estevão: "Algumas pessoas piedosas sepultaram Estêvão e guardaram luto solene por ele" $($ At 8,2$)$. Os cristãos praticavam estes rituais de sepultamento

1 José ALDAZÁVAL, Vocabulário básico de Liturgia, p.126. 
porque tinham a firme esperança na ressurreição dos mortos, isto é, eram convictos de uma esperança pascal. "Irmãos, não queremos deixar-vos na ignorância quanto aos que adormeceram, pra que não fiqueis tristes como os outros, que não tem esperança. Com efeito, se cremos que Jesus morreu e ressuscitou, cremos igualmente que Deus, por meio de Jesus, reunirá consigo os que adormeceram" (1Ts 4,13-14).

O Concílio Vaticano II (1962-1965), fazendo uma releitura das fontes primeiras da Igreja, assim se exprime: "A Igreja dos viandantes, desde os primeiros tempos do cristianismo, venerou com grande piedade a memória dos defuntos e ofereceu sufrágios por eles" (LG 50). E o novo ritual da Exéquias, que também é fruto da Reforma Litúrgica da Igreja do Vaticano II, afirma: "A Igreja oferece pelos defuntos o Sacrifício Eucarístico, memorial da Páscoa de Cristo, eleva orações e faz sufrágios por eles, para que, pela comunhão de todos os membros de Cristo, todos aproveitem os frutos da liturgia: auxílio espiritual para os defuntos, consolação e esperança para os que choram a morte" (IGRE 1).

Como podemos perceber, a Igreja, desde o início e ao longo de toda a sua história, através da celebração do rito com o corpo presente, acompanha os seus filhos até o fim e realiza a entrega destes seus filhos a Deus.

\section{c) Pandemia}

O termo pandemia é bastante novo para a maioria de todos

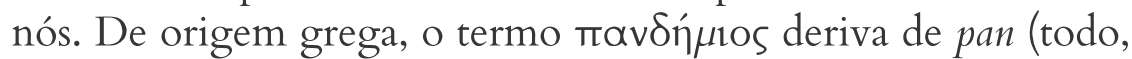
tudo) e demos (povo). Neste sentido, pandemia significa todo o povo. Outros significados que se aproximam: "Doença infecciosa e contagiosa que se espalha muito rapidamente e acaba por atingir uma região inteira, um país, um continente, o universo"; "é o aumento anormal do número de pessoas contaminadas por uma doença, numa região determinada, num 
país e no mundo"; "é uma epidemia que se espalhou geograficamente, saindo do seu lugar de origem, especialmente falando de doenças contagiosas que assolam praticamente o mundo inteiro: pandemia de Covid-19"2. "Uma pandemia $\left(\pi \alpha v \delta \dot{n} \mu 10 s^{\prime}=\right.$ de todo o povo $)$ é uma epidemia de doença infecciosa que se espalha entre a população localizada numa grande região geográfica como, por exemplo, um continente, ou mesmo por todo o planeta Terra" 3.

Uma síntese bem interessante para entender a pandemia foime apresentada pelo amigo Luciano Mello, médico, professor, consultor e gestor hospitalar. A pandemia, o Dr. Mello a define como "uma epidemia (termo já de domínio geral) que se estenda geograficamente por grandes regiões, ignorando fronteiras, e, em especial, que atinja os cinco continentes com a ocorrência, em todos eles, de novos casos cuja origem não se possa detectar fora da região. Assim, é importante entender-se que toda pandemia é uma epidemia, mas nem toda epidemia é pandêmica”.

De acordo com a Organização Mundial da Saúde (OMS), "uma pandemia pode começar quando se reúnem estas três condições: a) $\mathrm{O}$ aparecimento de uma nova doença na população; b) $\mathrm{O}$ agente infecta humanos, causando uma doença séria; c) $\mathrm{O}$ agente espalha-se fácil e sustentavelmente entre humanos"4.

\section{Acompanhamento $\mathrm{x}$ isolamento}

No resgate etimológico das palavras Liturgia e Exéquias fica claro o que a Liturgia das Exéquias é o rito que a Igreja realiza para acompanhar o seu filho até o seu sepultamento. $\mathrm{O}$ Catecismo da Igreja Católica também ressalta este aspecto

2 https://www.dicio.com.br/pandemia/ Acesso em 8/7/2020.

3 https://pt.wikipedia.org/wiki/Pandemia Acesso em 8/7/2020.

4 https://pt.wikipedia.org/wiki/Pandemia Acesso em 8/7/2020. 
importante do acompanhamento; "A Igreja, que, como mãe, trouxe sacramentalmente em seu seio o cristão durante sua peregrinação terrena, acompanha-o ao final de sua caminhada para entregá-lo ‘às mãos do Pai'. Ela oferece ao Pai, em Cristo, o filho de sua graça e deposita na terra, na esperança, o germe do corpo que ressuscitará na glória. Esta oferenda é plenamente celebrada pelo Sacrifício Eucarístico...” (CIC 1683).

O Novo Ordo Exsequiarum (Novo Rito das Exéquias), promulgado em 1971, resgata alguns elementos importantes dos pontos de vista teológico e litúrgico que podem ser encontrados na eucologia (estudo das orações), nas rubricas, na simbologia, nos diversos ambientes das exéquias (casa, igreja, cemitério) e que servem para este ato de acompanhar o irmão da comunidade até a deposição de seu corpo.

\section{a) Um verdadeiro ato de acompanhar}

O ritual das Exéquias da Igreja Católica propõe o ato de acompanhar em duas direções: a primeira, está voltada ao defunto, isto é, ao filho que partiu e que a Igreja quer acompanhar a fim de entregá-lo a Deus; a segunda, volta-se aos mais próximos dele, ou seja, a Igreja dirige uma palavra de conforto aos presentes no funeral, através de todo o rito que vai acontecendo.

O novo ritual propõe três esquemas. $O$ primeiro envolve três lugares: a casa do defunto, a igreja e o cemitério. Destes três lugares podemos resgatar os seguintes aspectos que mostram a presença da Igreja numa atitude de acompanhamento do defunto e de sua família.

- Ao ver o familiar partir, lá está a presença da Igreja através de um ministro (ordenado ou não) ou de algum cristão que marca presença e acompanha (consola) a família;

- O velório é acompanhado da récita do rosário, de orações, de cantos e de celebrações da Palavra...;

- Em algumas comunidades, as famílias se revezam para 
acompanhar os familiares enlutados durante o velório, mesmo passando noites inteiras e frias junto a eles que velam o seu ente querido;

- Durante o fechamento do caixão e seu translado até o templo (Igreja), lá está a presença da Igreja que acompanha e ora;

- Na celebração pública e comunitária, a Igreja celebra a Liturgia da Palavra onde encontra a luz de Deus para a dor, para o sofrimento e para a morte, e a Liturgia Eucarística onde oferece o Sacrifício em sufrágio do irmão que partiu; a celebração eucarística manifesta a vinculação da morte do cristão com o mistério pascal de Jesus Cristo ${ }^{5}$;

- No cortejo até o cemitério, a Igreja acompanha o cristão com sua dor e oração;

- Junto à sepultura lá está a Igreja através de seus ministros e da comunidade para abençoar o lugar que abrigará o corpo do falecido.

Desde sua partida, passando pela celebração de corpo presente até o seu sepultamento, a Igreja acompanha os seus filhos. O que o ritual propõe vai além de uma simples cerimônia de encomendação de defuntos durante o velório. É toda uma dinâmica pascal de acompanhamento para que o irmão falecido seja acolhido à morada definitiva junto de Deus. $\mathrm{O}$ novo ritual também expressa que a celebração das exéquias é um direito do cristão e um dever dos ministros da Igreja e da comunidade eclesial para com os irmãos falecidos.

Neste primeiro esquema, a Igreja procurou manter uma prática existente já há muito tempo e que acontece ainda hoje,

5 Segundo o Ritual das Exéquias, a Missa exequial é proibida no Tríduo Pascal, nas solenidades de preceito e nos domingos do Advento, da Quaresma e da Páscoa. Quando a Missa exequial não é permitida, pode-se usar uma leitura dentre aquelas que estão incluídas no Leccionário dos Defuntos, a não ser que seja um dia do Tríduo Pascal, do Natal do Senhor, da Epifania, da Ascensão, do Pentecostes, do Santíssimo Corpo e Sangue de Cristo ou outra solenidade de preceito (IGRE 6). 
sobretudo nas famílias e comunidades rurais.

A urbanização rompeu com vários aspectos destes ritos. Para isso, o novo ritual propõe um segundo esquema através de dois momentos: na capela mortuária (geralmente próxima ou junto ao cemitério) e na sepultura.

Na capela mortuária geralmente é realizada uma Celebração da Palavra exequial. Este segundo momento não oferece a Celebração Eucarística. Ela se realizará posteriormente sem a presença do corpo do falecido. É o que geralmente acontece com as missas de sétimo dia. Não houve missa de corpo presente, mas é celebrada a missa na intenção do irmão que faleceu, próximo ao sétimo dia de seu falecimento.

Através dos ritos de encomendação e de sepultamento, a Igreja mostra sua presença e acompanha com suas orações o irmão que morreu.

- Nos cantos e orações que trazem em sua teologia o caráter pascal;

- Na Celebração da Palavra que resgata a presença de Cristo na hora da dor e da morte;

- Nos sinais sacramentais como a água, a luz, a cruz, as flores, que resgatam os Sacramentos celebrados durante a vida, sobretudo pelos sinais do Batismo;

- Nos gestos sacramentais, principalmente os de aspergir e incensar, que purificam o corpo e o abençoam;

- No fechamento do caixão e na despedida dos familiares e amigos;

- No cortejo até a sepultura cantando e orando;

- Na oração junto à sepultura e na benção da mesma.

Mesmo neste esquema mais simplificado, o ritual traz a presença da Igreja que acompanha, na fé, na presença e na oração, o seu irmão que partiu. 
O terceiro esquema, mais simplificado ainda, propõe apenas um ritual de exéquias na casa do defunto. É um ritual pouco usado, visto que o velório é feito em capelas mortuárias autorizadas pelas autoridades sanitárias. Mesmo assim, o ritual traz uma Liturgia da Palavra e orações de encomendação feitas todas na casa do defunto. Este esquema também mostra a presença da Igreja que acompanha com a oração e a súplica pedindo que Deus acolha na eternidade o irmão que faleceu.

A pandemia da Covid 19 rompeu com vários elementos litúrgicos. Em relação às exéquias, a primeira orientação da CNBB foi a de não mais realizar os ritos fúnebres com missa, mas apenas uma cerimônia simples de encomendação.

$\mathrm{O}$ vírus, além de provocar muitas inseguranças, trouxe muito medo. Uma boa parte dos padres resistiam em marcar presença nas celebrações de exéquias. Os que colocaram a missão acima de suas vidas corriam o risco de serem contaminados e fato é que muitos padres, diáconos e agentes de pastoral, perderam suas vidas ceifadas pelo coronavírus.

Em outras situações, como acompanhamos em outros países, sobretudo em Bérgamo (Itália), os mortos eram carregados em comboios para serem cremados em cidades vizinhas. Noutros lugares, os caixões fúnebres eram colocados em valas comuns, como foi em Hart Island (Nova York) e Manaus, no Brasil. Em ambos os casos, não foi possível fazer um ritual de encomendação. A pandemia provocou o distanciamento social. E, orientados pelas autoridades sanitárias, a Igreja fechou suas portas, não pode celebrar a vida do irmão que partiu e, em muitas situações, também não foi possível aspergir o caixão do falecido e, muito menos, o seu lugar de sepultura.

A pandemia provocou o isolamento social e, este, não permitiu que a Igreja pudesse fazer um verdadeiro ato de acompanhamento tão importante e necessário para encomendar a Deus a vida do irmão e para consolar e confortar os que 
perderam seu ente querido. A pandemia tirou, pela proibição da aproximação entre as pessoas, a família e os amigos de realizaram o ritual de exéquias que permite fortalecer a fé na esperança da ressurreição final. "Embora o costume de enterrar seus mortos seja algo conatural ao ser humano e os funerais uma venerável e não inútil tradição cristã, segundo Santo Agostinho, as exéquias são mais úteis aos vivos do que aos mortos"6.

A celebração ritual das exéquias permite à família do falecido amenizar a dor e o sofrimento, ouvir palavras de esperança que brotam da Sagrada Escritura, dos cantos, das orações, das palavras do padre e elaborar melhor o luto da morte. Mas tudo isso foi suprimido, ou na melhor das situações, foi simplificado e ficou uma lacuna que precisa ser elaborada.

É preciso, como escreve a filósofa italiana Donatella Di Cesare, fazer um ritual público para elaborar o luto. "É repugnante a modalidade do sepultamento, ferozmente asséptico, impiedosamente apressado. Incomoda o expurgo da morte na cidade. [...] Não podemos aceitar que o distanciamento resulte em um sumário isolamento das vítimas"7.

$\mathrm{O}$ rito nos torna humanos, a pandemia, ao invés, nos desapropria do luto, escreve a jornalista italiana Concita de Gregorio num artigo publicado pelo Instituto Humanitas Unisinos (IHU). Concita assim afirma: "a maior tragédia nesta grande tragédia são as mortes solitárias”. Sobre os funerais ela é mais incisiva: "O rito do funeral nos falta. Porque no funeral a vida toda passa diante de nós. [...] Quem somos, sem o rito que nos consagra humanos. E todos, todos conhecemos nestes dias a dor inominável de não poder viajar para nos despedir do grande amigo" ${ }^{\text {. }}$

6 CNBB, Nossa Páscoa, p.10.

7 http://www.ihu.unisinos.br/78-noticias/598252-um-ritual-publico-para-elaboraro-luto Acesso em 10.7.2020.

8 http://www.ihu.unisinos.br/78-noticias/597543-morrer-sozinhos-a-epidemiatambem-nos-desapropria-do-luto-o-rito-que-nos-torna-humanos Acesso em 10.7.2020. 
A pandemia rompeu com um elemento importante da vida cristã que é a celebração das exéquias, momento importante de passagem, de fé na vida eterna e de elaboração do luto pela perda do ente querido.

\section{b) O resgate da eclesialidade da liturgia exequial}

As celebrações exequiais são sempre celebrações litúrgicas da Igreja (CIC 1684). "O cristão não morre sozinho. Sua partida está cercada da comunidade dos crentes, a qual, por sua vez, encarrega-se de encomendá-lo à comunidade eclesial"9.

$\mathrm{Na}$ celebração exequial é a comunidade que está presente para orar e suplicar a Deus pela vida do irmão falecido. Naquele defunto deitado no caixão fúnebre está um corpo em que o Espírito Santo habitou e é este corpo que é chamado à ressurreição da vida eterna como afirma São Paulo (1Cor 6,1920). Portanto, na celebração das exéquias, a Igreja continua cuidando daquele corpo, pois foi o corpo em que derramou a água no Batismo, ungiu com óleo dos catecúmenos e dos enfermos, alimentou com o pão eucarístico, impôs as mãos para ser crismado e ordenado, abençoou para se unir em matrimônio, perdoou os seus pecados. Aquele corpo "foi instrumento da eficácia dos sacramentos, uma vez convertido em cadáver continua sendo objeto de cuidado solícito da mãe Igreja"10. É por isso que a Igreja continua aspergindo, incensando e iluminando aquele corpo e, mesmo sendo o corpo de um morto, continua tratando-o com respeito. Para a Igreja, o corpo de um cristão é sagrado, pois "é todo o homem, alma e corpo formando uma unidade vital, que é objeto de salvação"11.

9 Alfredo POUILLY, A celebração da morte do cristão, In: CELAM, A celebração do mistério pascal, p.214.

10 Alfredo POUILLY, A celebração da morte do cristão, In: CELAM, A celebração do mistério pascal, p.214.

11 J. LLOPIS, Exéquias, In: Dionísio BORÓBIO (Org.), A celebração da Igreja 2: Sacramentos, p.618. 
A celebração exequial resgata, portanto, a dimensão eclesial, a dimensão comunitária da liturgia. "A celebração deixou de ser ato exclusivo do ministro e adquiriu um tom mais eclesial e comunitário. Já não se reza apenas pelo defunto, mas também pelos vivos provados pela dor. A dimensão comunitária faz parte da identidade cristã, até na hora da morte" ${ }^{" 12}$.

$\mathrm{O}$ isolamento social provocado pela pandemia, porém, rompeu também com toda a dimensão eclesial. A comunidade cristã não pode mais participar dos rituais. Os próprios avisos de falecimento afirmavam que a cerimônia seria restrita à família ou parte dela. Portanto, os vizinhos, os amigos, os colegas de trabalho e outros tantos, não puderam participar. Como Igreja, ia apenas o padre e ele fazia tudo sozinho: cantava, invocava as orações, proclamava os textos da Sagrada Escritura, aspergia... Mas o padre sozinho não é Igreja. Embora a família poderia ser considerada igreja, as celebrações exequiais em tempos de pandemia provocaram muitos questionamentos, pois os ministérios (leitor, cantor e outros) foram dispensados; vários sinais simbólicos de exéquias foram suprimidos, as cerimônias foram simplificadas... e tudo isso rompe com o sentido mais profundo de toda a liturgia, isto é, de uma assembleia reunida como Corpo Místico de Cristo, sendo conduzida pelos seus mais variados ministérios litúrgicos (SC 7).

Passados alguns meses da pandemia, em algumas paróquias onde as autoridades sanitárias não restringem totalmente $o$ isolamento social, as exéquias são realizadas apenas no cemitério e de maneira simples. Depois do falecimento, o defunto é guardado na funerária ou colocado na capela mortuária do cemitério que fica fechada a maior parte do tempo. Com restrições, a família e alguns amigos se reúnem para fazer velório de duas a três horas. Mais tarde, o padre chega, faz a encomendação simples e já há a deposição do corpo na sepultura.

12 CNBB, Nossa Páscoa, p.16. 
Como afirmamos anteriormente, a liturgia das exéquias, tão rica para elaborar um rito de passagem, isto é, de entregar o irmão a Deus e de sentir a presença das pessoas mais caras do falecido, fica empobrecida. Tudo é realizado de maneira simples e rápida pelo medo do contágio do coronavírus. $\mathrm{O}$ isolamento social fere a dignidade de ser Igreja e de realizar a profundidade e a riqueza que são próprias da liturgia das exéquias: celebrar a dinâmica pascal.

\section{Celebrar as Exéquias é viver a Páscoa de Cristo}

A Congregação para o culto divino e os sacramentos, quando propôs a revisão do ritual de exéquias de 1614, o que estava em uso, tinha a preocupação de que o novo ritual (1969) deveria corresponder a duas exigências:

a) teológica: que fosse acentuado mais o carácter pascal da morte cristã, isto é, que a liturgia das exéquias, e toda a compreensão teológica dela que se encontra na instrução do próprio ritual, pudesse dar esta atenção a fim de recuperar o sentido da nossa vida cristã: a vida não termina na morte, ela continua na eternidade.

b) antropológica: o de perceber a diversidade das situações de acordo com os países, os ambientes e a idade do falecido.

Esta preocupação já tinha sido expressa pela Sacrosanctum Concilium, que trata da Liturgia, quando da revisão dos ritos fúnebres disse: "as exéquias devem exprimir melhor o caráter pascal da morte cristã. Adapta-se mais o rito às condições e tradições das várias regiões, mesmo no que respeita à cor litúrgica" (SC 81). No parágrafo seguinte trata das crianças: "faça-se a revisão do rito de sepultura das crianças enriquecendo-o de missa própria” (SC 82). 
Aqui no Brasil, a CNBB produziu um material próprio para as celebrações exequiais ${ }^{13}$. No capítulo que aprofunda a celebração cristã da morte, traz a seguinte afirmação:

No início, as exéquias cristãs caracterizavam-se por sua forte dimensão pascal. No entanto, com o passar do tempo, os cristãos foram se deixando influenciar por outras ideias e sentimentos. Perderam a certeza da salvação e passaram a ver a morte como acontecimento trágico e amedrontador. Esta situação perdurou até o século XX quando, de novo, a Igreja, por meio do Concílio Vaticano II, prescreveu que 'o rito das exéquias deve exprimir mais claramente a índole pascal da morte cristã’ (SC 81) ${ }^{14}$.

A reforma litúrgica do Concílio Vaticano II recuperou a força da expressão "o mistério pascal de Jesus Cristo" para significar o ser e a missão de Jesus no mundo e a continuação da sua obra através da Igreja para, na hora da morte, poder exprimir o caráter pascal da morte cristã.

O subsídio da CNBB, baseando-se no Catecismo da Igreja Católica e tendo como base as definições do Vaticano II, assim se expressa: "As exéquias não fazem parte nem dos sacramentos nem dos sacramentais. São celebrações parassacramentais. Elas tem em vista exprimir o caráter pascal da morte cristã. Anunciam à comunidade reunida a vida eterna, ao mesmo tempo que realçam o caráter de provisoriedade da vida aqui na terra (cf. CIC 1684-1685)"15.

Numa outra passagem da Sacrosanctum Concilium encontramos esta rica relação entre as duas liturgias: aquela que celebramos agora e a definitiva que virá na glória. "Na liturgia da terra nós participamos, saboreando-a já, da liturgia celeste, que se celebra na cidade santa de Jerusalém, para a qual nos encaminhamos como peregrinos, onde o Cristo está sentado à

13 CNBB. Nossa Páscoa: subsídios para a celebração da esperança. São Paulo: Paulus, 2003.

14 CNBB, Nossa Páscoa, p.11.

15 CNBB, Nossa Páscoa, p.7. 


\section{direita de Deus...” (SC 8).}

Os documentos mencionados nos ajudam a entender que a Igreja se preocupa com a vida e, ao celebrar as exéquias, quer ajudar a compreender que a vida é mais do que um corpo físico, a vida é divina, ela está voltada para o eterno. Desta forma, a liturgia exequial nos faz mergulhar no Mistério de Cristo e acreditar que a vida não termina na morte, mas ela é uma passagem para a vida eterna.

A morte! Ah, a morte! Como compreendê-la? Bem! Não vamos fazer um tratado teológico-escatológico da morte. Gostaríamos apenas de trazer duas situações muito presentes na sociedade de hoje, como duas marcas e que, talvez, as tenhamos já experienciado. De um lado é possível perceber a negação da morte. De outro lado, a morte pode ser ocasião de espetáculo. Estas questões serão confrontadas com a fé cristã e iluminadas com a vida do Cristo ressuscitado.

\section{a) Negação da morte}

De um lado, percebemos que há a negação da morte. $\mathrm{Na}$ sociedade atual a morte é vista como um "fim tenebroso". Por isso, se nega a morte ou ao menos a sociedade procura torná-la o mais ausente possível. Em muitas situações, sobretudo quando a morte acontece em Unidades Hospitalares de Tratamentos Intensivos, ela é escondida, pois a família e os amigos não participam, não acompanham a partida do ente querido. Em outras situações a família somente vê o seu ente querido já vestido, maquiado, embalsamado... que parece mais uma pessoa dormindo do que um defunto.

Há situações em que a morte não é revelada como, por exemplo, quando uma criança perde a mãe, alguém diz que ela foi passear. Esta criança, todos os dias fica esperando sua mãe voltar do passeio. No entanto, ela não volta mais. E assim teríamos outros tantos exemplos. 
$\mathrm{Na}$ mesma linha vão as teologias em torno da morte: "chegou a sua hora"; "Deus quis assim"; "Deus queria uma pessoa boa lá no céu”... São afirmações que nunca deveriam ser ditas para justificar a morte de alguma pessoa. Deus não definiu nem dia, nem hora, nem local, nem situação de morte para nenhuma pessoa. E, muito menos, Deus não quer mortes trágicas. Se uma pessoa bebe e dirige, ou dirige em alta velocidade e de maneira imprudente, esta pessoa está muito mais suscetível a um acidente com possibilidade de morte dela e dos ocupantes, do que um motorista prudente e responsável. Se uma pessoa morre de acidente por imprudência, como podemos afirmar que chegou a sua hora? Deus não quer que ninguém, mesmo o mais imprudente motorista, morra de acidente. Por isso, não tem a hora da morte. A hora, é morrer de idade avançada e de morte natural. Quando alguma pessoa é imprudente e não cuida do seu corpo, pode antecipar a sua morte. Portanto, a hora é cada um que traça e não Deus.

Outra questão que nos intriga é toda esta cultura de permanecer jovem. Para isso, são ingeridas tantas drogas no organismo, são injetados tantos anabolizantes e outros produtos para parecer sempre jovem, "com tudo em cima". A vida tem o seu processo natural. Reconhecer e assumir a morte é admitir os limites da própria existência, bem como a falência do sistema contemporâneo, incapaz de saciar uma civilização desejosa de felicidade e de vida sem limites. Para muitas pessoas, a experiência da morte continua sendo uma ameaça e um extremo desconforto, um atentado à autossuficiência pretendida pela sociedade moderna.

\section{b) Espetacularização da morte}

Por outro lado, a morte é vista como um espetáculo de curiosidade, um show para expectadores. Quando acontece um acidente de trânsito, quase sempre os que estão passando nem conhecem a vítima, mas, curiosos, já estão fazendo vídeos e 
postando nas suas redes sociais. Às vezes a própria vítima é exposta sem escrúpulos. Não há o respeito pela pessoa que perdeu a vida e pela família que chora a morte. Atitudes assim ferem a dignidade das pessoas.

Outra situação é quando a mídia faz espetáculo a partir da morte de alguém. Os mais próximos das vítimas nem podem fazer luto pelo seu familiar porque a mídia já está querendo impressionar a todos. E se for a morte de uma pessoa famosa então há, inclusive, uma programação especial para espetacularizar a morte.

Tanto a maquiagem da morte, quanto sua espetacularização, contribuem para a banalização da morte e, com ela, perderamse muitas atitudes rituais que ajudavam a enfrentá-la de maneira mais próxima e natural possível.

Diante da morte, a Igreja sempre procura levar uma palavra de conforto, de fé e de esperança para aquelas pessoas enlutadas, porque a Igreja acredita na vida eterna. Queremos trazer dois aspectos importantes dos quais a Igreja acredita e que podem nos ajudar a caminhar nesta vida tendo como horizonte a vida eterna.

\section{a) A morte como nascimento para a vida eterna}

Já afirmamos que a Igreja, quando celebra a liturgia das exéquias, por meio de seus textos sagrados, cantos, orações, sinais, gestos rituais e pessoas, ajuda a comunidade cristã a acompanhar e fazer sua última saudação ao um filho seu que faleceu. A celebração se torna, portanto, consolo e esperança para os vivos. Ao mesmo tempo, porém, a Igreja intercede a Deus pela vida do falecido, suplica a Deus a intercessão espiritual daquele que partiu para que esteja em comunhão com Cristo (CIC 1690). A própria Instrução Geral do Ritual de Exéquias exprime isto quando exorta os sacerdotes da Igreja: “...O sacerdote deve ter diante dos olhos, não só a pessoa de 
cada morto e as circunstâncias de sua morte, (...) deve considerar a dor e as necessidades da vida cristã dos familiares" (IGRE 18).

A comunidade que celebra, ou a Igreja quando dirige suas orações diante da morte de uma pessoa, sempre procura suscitar a esperança dos vivos na ressurreição final. Para os batizados é profissão de fé: “...Creio em Jesus Cristo....”; “...que ressuscitou ao terceiro dia..."; "Creio na ressurreição da carne e na vida eterna”. Noutra oração do Creio: "Professo um só batismo para remissão dos pecados. E espero a ressurreição dos mortos e a vida do mundo que há de vir".

Na compreensão paulina, sobretudo da carta aos Romanos, há toda uma teologia que relaciona o Sacramento do Batismo com a morte e ressurreição de Cristo ( $\mathrm{Rm}$ 6,1-11). "Pelo batismo fomos sepultados juntamente com ele na morte, para que, como Cristo foi ressuscitado dos mortos por meio da glória do Pai, assim também nós caminhemos em uma vida nova" (Rm 6,4). Participar da morte de Cristo significa fazer parte da vitória definitiva que ele estabeleceu sobre o pecado ( $\mathrm{Rm} 6,6 \mathrm{~s})$, e pela qual os cristãos podem ser considerados "mortos para o pecado, porém vivos para Deus, no Cristo Jesus” (Rm 6,11).

A morte, na teologia paulina, já foi destruída no dia do Batismo. Lá o pecado e a morte foram sepultados na água. E, na água batismal, o cristão já nasceu para esta vida nova que se torna definitiva quando o corpo cessar seu ciclo terreno. Neste momento, o cristão nasce para a vida eterna. Toda liturgia exequial, portanto, celebra esta nova vida em Cristo. Alguns exemplos das orações que encontramos no Ritual das Exéquias.

\section{b) Vida nova em Cristo: orações do Ritual das Exéquias}

O ritual das exéquias traz várias sugestões de orações para momentos distintos da liturgia. Vamos escolher algumas das orações que nos ajudam a compreender o que a Igreja reza a Deus. 
Na oração da vigília pelo defunto: Deus Pai todo-poderoso, que, pelo Batismo, nos configurastes com a morte e ressurreição do vosso Filho, concedei benignamente que o vosso servo N., liberto desta vida mortal, seja associado ao convívio dos vossos eleitos. Por Cristo, nosso Senhor.

Na celebração da Palavra durante o velório: Senhor, nosso Deus, que, pelo vosso amor quisestes que o nosso irmão N., através da morte, fosse configurado com Cristo, que por nós morreu na cruz, pela graça renovadora da Páscoa do vosso Filho, afastai do vosso servo todo o vestígio da corrupção terrena, para que, marcado já na sua vida mortal com o selo do Espírito Santo, ressuscite para a vida eterna da vossa glória. Por Cristo, nosso Senhor.

Na celebração das exéquias sem missa: Senhor, nosso Deus, sempre disposto a compadecer-Vos e a perdoar, escutai benignamente as súplicas que Vos dirigimos pelo vosso servo N., que (hoje) chamastes deste mundo à vossa presença; e, porque acreditou e esperou em Vós, conduzi-o à sua pátria verdadeira, para tomar parte nas alegrias eternas. PNSJC.

$\mathrm{Na}$ oração da coleta na Missa de Exéquias: Senhor, Pai santo, Deus eterno e onipotente, humildemente Vos pedimos por este nosso irmão N.: perdoai-lhe as suas culpas e concedei-lhe o descanso eterno na paz da vossa presença, em companhia dos vossos Santos. Fazei que da escuridão da morte passe ao esplendor da vossa luz e viva convosco para sempre na glória do vosso reino. Por Cristo, nosso Senhor.

$\mathrm{Na}$ oração sobre as oferendas na Missa de Exéquias: Deus de bondade infinita, que purificastes na água do Batismo o vosso servo $N$, purificai-o também agora no Sangue de Cristo, por este sacrifício de reconciliação, e recebei-o nos braços da vossa misericórdia. Por Cristo, nosso Senhor.

$\mathrm{Na}$ oração depois da comunhão na Missa de Exéquias: Alimentados neste sacramento do vosso Filho, que por nós foi imolado e ressuscitou glorioso, humildemente Vos suplicamos, Senhor, pelo vosso servo N., para que, purificado pelo mistério pascal, alcance a glória da ressurreição futura. Por Cristo, nosso Senhor. 
$\mathrm{Na}$ exortação que antecede a aspersão e a incensação (quando há) e a oração de encomendação no final da Missa de Exéquias: Pelo batismo, este nosso irmão tornou-se verdadeiramente filho de Deus, membro de Cristo ressuscitado e templo do Espírito Santo. A água que agora vamos derramar sobre o seu corpo nos recorda essa admirável graça batismal, que o preparou para ser concidadão dos Santos no Céu. (O incenso com que vamos perfumar os seus despojos será símbolo da sua dignidade de templo de Deus.) O Senhor aumente em nós a esperança de que este nosso irmão, chamado a ser pedra viva do templo eterno de Deus, ressuscitará gloriosamente com Cristo.

$\mathrm{Na}$ oração de bênção da sepultura: Senhor Deus, criador do céu e da terra, que, pelo Batismo, salvastes o homem do cativeiro da morte e o unistes ao triunfo pascal de Cristo vosso Filho, para que também nós, membros do seu Corpo, nos tornássemos participantes da sua ressurreição, abençoai a sepultura do vosso servo N., e fazei que nela tenha um sono tranquilo e ressuscite no último dia com os vossos Santos. Por Cristo, nosso Senhor.

Foram escolhidas estas orações do Ritual das Exéquias, mas a maioria delas relaciona a morte à ressurreição em Cristo ou à glória futura ou à vida eterna. Várias delas também fazem referência à morte que foi vencida pelo Batismo e a nova vida que o cristão passa a viver. Todos elas, portanto, recuperam este elemento teológico importante que faz ver a morte dentro de toda a dinâmica pascal.

\section{Conclusão}

Partindo das Orações e da Instrução Geral do Ritual das Exéquias, o texto procurou aprofundar a importância da presença da Igreja nas exéquias de seus filhos. Em tempo de pandemia, porém, nem sempre foi possível esta presença e este acompanhamento ou, em muitas situações, a celebração exequial foi realizada de forma reduzida e até simplificada e à distância. 
As orações das exéquias procuram afirmar a fé da comunidade cristã na vida eterna. Em tempos de calamidades, se faz ainda mais necessário afirmar esta teologia. Nossos olhares estavam atônitos vendo tantas mortes frias, cruéis e dolorosas. Sem poder fazer um ritual digno é preciso afirmar esta perspectiva pascal que todo o Ritual das Exéquias tão bem coloca por meio de toda a sua eucologia.

Muitos familiares não puderam fazer velório e despedida digna, outros nem o adeus conseguiram dar. A Igreja nos consola, pois ela acredita e prega que todos nós poderemos, na eternidade, nos encontrar novamente com estes irmãos que já partiram. Quem sabe uma celebração com Liturgia de Exéquias por todos estes irmãos que já partiram, num lugar sagrado, simbólico, poderia amenizar a perda, elaborar o luto e fortalecer a fé na ressurreição à vida eterna.

\section{Referências Bibliográficas}

ALDAZÁBAL, José. Vocabulário básico de Liturgia. São Paulo: Paulinas, 2013. Enterro, p.126; Exéquias, p.142-143.

BÍBLIA SAGRADA. Tradução oficial da CNBB. Brasília: Ed. CNBB, 2018. BROVELLI, F. Exéquias. In: SARTORE, Domenico; TRIACCA, Achille M. Dicionário de Liturgia. São Paulo: Paulus, 1992, p.426-436.

CATECISMO DA IGREJA CATÓLICA. Petrópolis: Vozes, 1993, par.1680-1690.

CNBB. Nossa Páscoa: subsídios para a celebração da esperança. São Paulo: Paulus, 2015, 8aed.

DOCUMENTOS DO CONCÍLIO ECUMÊNICO VATICANO II. São Paulo: Paulus, 2014, 7aed. In: Constituição Sacrosanctum Concilium sobre a Sagrada Liturgia, p.33-79.

https://pt.wikipedia.org/wiki/Pandemia Acesso em 8/7/2020. https://www.dicio.com.br/pandemia/ Acesso em 8/7/2020. http://www.ihu.unisinos.br/78-noticias/597543-morrer-sozinhos-aepidemia-tambem-nos-desapropria-do-luto-o-rito-que-nos-torna-humanos Acesso em 10.7.2020. 
http://www.ihu.unisinos.br/78-noticias/598252-um-ritual-publico-paraelaborar-o-luto Acesso em 10.7.2020.

LLOPIS, J. Exéquias. In: BOROBIO, Dionisio (Org). A celebração da Igreja 2: Sacramentos. São Paulo: Loyola, 1993, p.615-627.

POUILLY, Alfredo. A celebração da morte do cristão. In: CELAM. A celebração do mistério pascal: outras expressões celebrativas do mistério pascal e a liturgia na vida da Igreja. São Paulo: Paulus, 2007. Manual de Liturgia IV, p.209-217.

RITUAL DAS EXÉQUIAS. In: BECKHÄUSER, Alberto (org). Presbiteral. Petrópolis: Vozes, 2008, 2ªd. p.453-536. 